\title{
EXECUTIVE POWERS IN RELATIONS WITH THE PARLIAMENT. PART I \\ O. ŞARAMET
}

\author{
Oana Şaramet \\ Faculty of Law, Department of Law \\ Transilvania University of Braşov, Braşov, Romania \\ *Correspondence: Oana Şaramet, Transilvania University of Braşov, \\ Eroilor Boulevard no.25, Braşov, România \\ E-mail: oana_saramet_2005@yahoo.com
}

\begin{abstract}
By art. 1 para. (4), Romanian Constitution, republished, enshrined the principle of separation and balance of powers. Therefore, this principle implies the existence of collaboration but also of a mutual control between these powers, including between the legislative and executive power, thus being expressed the balance between these two powers. By constitutional established powers, the two central authorities of the executive power - the President of Romania and the Government - will participate at the observance and application of this principle, including by those duties they perform in their relations with the legislative power.
\end{abstract}

Keywords: head of state, legislative power, convening, dissolution, messages, promulgation

\section{Introduction}

Based on the constitutional provisions in force, we can identify two functions of the Romanian executive, namely the executive one and the administrative one. In our view, the determination of the powers which enable fulfilling these functions it is possible by reporting to the executive structures and, therefore, the specific functions of each of them. Motivation of this allegation is that the powers enshrined in the constitution and laws in the task of these structures, in fact represents their competence, namely of the head of state - the president or monarch, and of the government. So we appreciate as difficult, if not impossible, to talk about the competence of the executive as stand-alone entity, more so as most contemporary constitutional systems have established a dualist executive and not a monocratic one.

\section{Convening of Parliament ${ }^{1}$}

According to Article 63 para (3) of our Constitution, republished, the newly elected Parliament convened by the President of Romania, within 20 days from the election ${ }^{2}$, but also in his request, the Chamber of Deputies and the Senate can also meet in special sessions.

\footnotetext{
${ }^{1}$ See O. Şaramet, "Powers of the Romanian President in relations with Parliament. Convening and dissolution of Parliament" in I. Boldea, coordinator, Debates on globalization. approaching national identity through intercultural dialogue. Studies and article. Section: Social studies, "Arhipelag Press XXI", Târgu-Mureş, 2015, pag. 721-729.
} 


\section{EXECUTIVE POWERS IN RELATIONS WITH THE PARLIAMENT. PART I}

And so, for the first session after the elections, the constituent legislator has the obligation of the President of Romania, to convene the new parliament, thus making a prerogative - reminiscent of the period in which the monarch was trying to reserve some procedural paths meant to assure a further influence on the new legislative ${ }^{3}$, prerogative that was taken by the constitutions of states that have established a parliamentary regime or a semi-presidential one. Starting from the premise that at the time they would meet in their first session after the elections, neither the Chambers of Deputies nor the Senate have designated internal teams of work, so not even their presidents who could take over the attribution from the President of Romania, appreciated by our lawgiver as the latter - authority placed at "the highest level of the hierarchy of executive power"4, with permanent activity, not knowing a "presidential vacation" similar to the parliamentary one, to be the one to convene the newly elected parliament in its first session. However, taking into account the examples offered by the provisions of constitutions ${ }^{5}$, and also the provisions and dispositions of our Constitution

\footnotetext{
${ }^{2}$ Provisions similar to those in our Constitution we can find in Constitution of Poland, art.109 para.(2), settled the right of the President of Republic to convene the newly elected House of Representatives - Sejm - and Senate, within 30 days from the date of the elections, in their first session. This Constitution was consulted on: https://www.constituteproject.org/constitution/Poland_2009.pdf?lang=en, accessed: 25.10.2015.

${ }^{3}$ See T. Drăganu, Drept constituţional şi instituţii politice. Tratat elementar, vol. II, „Lumina Lex” Publishing House, Bucharest, 2000, pag.240. This power of the head of state is found today in the constitutions of countries with constitutional monarchies. Thus, for example, art.35 para.(1) of the Constitution of Denmark, adopted on June 5, 1953, provides that A newly elected Folketing shall assemble at twelve o'clock noon on the twelfth week-day after the day of election, unless the King has previously convoked a meeting of its Members. This Constitution was consulted on: https://www.constituteproject.org/constitution/Denmark_1953.pdf?lang=en, accessed: 25.10.2015. Likewise are the provisions of the Constitution of Norway, adopted on May 17, 1814, the King, according to art.68, can, by reason of extraordinary circumstances, such as hostile invasion or infectious disease, designates another town in the Realm for the purpose, to assemble on the first weekday in October every year in the capital of the Realm. When the Storting is not assembled, it may be summoned by the King if he finds it necessary, according to art. 69. This Constitution was consulted on: https://www.constituteproject.org/constitution/Norway_2015.pdf?lang=en, accessed: 25.10.2015. More than this the Grand Duke of Luxembourg, according to art.72 para.(3) of Constitution of Luxembourg, adopted on October 17, 1868, opens and closes each ordinary session of the Chamber either in person, or in his name

by his proxy appointed for that purpose. This Constitution was consulted on: https://www.constituteproject.org/constitution/Luxembourg_2009.pdf?lang=en, accessed: 25.10.2015. Art.62 point b) of Constitution of Spain, entered into force on December 29, 1978, provides the same specifying that the King is the one who summon and dissolve the Cortes Generales and to call for elections under the terms provided for in the Constitution. This Constitution was consulted on: https://www.constituteproject.org/constitution/Spain_2011.pdf?lang=en, accessed: 25.10.2015. We can observe that although some constitutions have provided a certain date when newly elected parliaments can meet, they have recognized that the monarch is still able to convene parliament in extraordinary sessions.

${ }^{4}$ See T. Drăganu, Drept constituţional şi instituţii politice. Tratat elementar, vol. II, „Lumina Lex” Publishing House, Bucharest, 2000, pag. 240.

5 Compared to them, we can mention examples from other constitutions. Thus Article $133 \mathrm{c})$ from the Constitution of Portugal recognizes the President's ability to convene in extraordinary assembly the Republic, only on emergencies, in the same way as the provisions in Article 63 from the Constitution of Argentina, with the specification that in this case it is recognized the President's possibility to extend a regular session. Constitution of Portugal was consulted on: https://www.constituteproject.org/constitution/Portugal_2005.pdf?lang=en, accessed: 25.10.2015. Constitution of Argentina was consulted on: https://www.constituteproject.org/constitution/Argentina_1994.pdf?lang=en, accessed: 25.10 .2015 . In these cases, the constituent legislator preferred to score a date or a period in which the new elected Parliament to convene its first session, without according this attribution to the head of state. Therefore in Portugal, according to Article 173 para (1), thesis I, the Republic Assembly shall meet on the third day subsequent to the day in which the final results of the election were communicated.
} 


\section{O. Şaramet}

form 1866 and $1923^{6}$, we appreciate that this attribution of the President can be replaced with the institutional obligation imposed by constitutional provisions that the newly elected parliament to convene at a certain time or after a certain amount of time from the established and communicated final result of the elections. An additional argument against this proposal of enactment of the law is, in principle, the fact that in the case where the President of Romania does not convene the newly elected Parliament within 20 days from the elections, there will be a meeting.

Like most constitutions ${ }^{7}$, our Constitution recognizes the right of the Head of State to convene the Parliament in an extraordinary session, in certain prescribed conditions, with or without prior consultation of other authorities, as is the Government or internal teams of work of the Parliament or political parties represented by the Legislative. Thus, although the provisions of Article 66 para (3) of our Constitution does specify only that the President of Romania or the permanent office of each Chamber or at least a third of the senators and deputies can demand convening of the Chamber of Deputies and Senate in an extraordinary session, the Regulations of the two Chambers specify the conditions that must be met when such a request is to be taken into consideration. Both Article 81 para (2) and (4) of the Regulations of the Senate ${ }^{8}$, and Article 84 para (3) from the Regulation of the Chamber of Deputies $^{9}$ stated that any request of convening any extraordinary session, regardless of which of those entitled formulated it, shall be done in writing and need to contain the following: the reason, the proposed agenda, and also the duration of the session. Lack of any of these elements and the rejection of the proposed agenda, by the Chamber, will not allow the extraordinary session to take place. But, while the demand for convening is formulated, for

\footnotetext{
${ }^{6}$ In this respect, see the provisions of Article 95, para (1), (4), (5), (6), (7) and (8) from our Constitution from 1866, namely Article 90 para (1), (4), (5), (6), (7) and (8) from the Constitution of 1923. The constitutional rules recognize the right of the King to convene the Assemblies in extraordinary sessions, and to dissolve both Chambers and just one of them, to present a message at the beginning of a session, to close the works of the Assembly. It is recognized the right to convene the Parliament - National Representation, only just before the time when the two Assemblies should meet to make the law, namely $15^{\text {th }}$ of October of each year.

${ }^{7}$ For example, the provisions of Article 84 para (2) from the Constitution of Slovenia, they recognize the Republic President's right to request the convening of a special session of the National Assembly - the Slovenian Parliament. Constitution of Slovenia was consulted on: https://www.constituteproject.org/constitution/Slovenia_2013.pdf?lang=en, accessed: 25.10.2015. In exchange, the constituent French legislator recognizes the Prime Minister's, and not the President's, right to ask that the Parliament meet in an extraordinary session, according to Article 29 para (1) from the Constitution, but, if the Parliament does not meet in right, the opening and closing of the extraordinary sessions will be discreetly made by the President of the Republic. Constitution of France was consulted on: https://www.constituteproject.org/constitution/France_2008.pdf?lang=en, accessed: 25.10.2015. Appreciated by the French doctrine as being an attribution, a competence tied to the French President against which his discretionary power could not manifest, not even in a period of cohabitation, practice has imposed modifying this point of view. Thus, presidents like Du Galle or Mitterrand have refused to sign such decree which also had justified the doctrine to assert that the final decision to convene or not in an extraordinary session which, in fact, is the decision of the French President. The amendment of the Constitution in the year 1995 and introducing a unique session of the Parliament has been appreciated in the doctrine as being one of the ways to quit the convening of the Parliament in an extraordinary session, and, implicitly, the possibility of the Republic's President to manifest the discretion, and to avoid possible political conflicts, especially the ones between him and Prime Minister, him and the Parliament. In this regard, see H. Portelli, Droit constitutionnel, Dalloz Publishing House, Paris, 1999, pag.204, and also pag.251.

${ }^{8}$ See: https://www.senat.ro/pagini/reg_sen/reg_senat.htm; accessed: 25.10.2015.

${ }^{9}$ See: http://www.cdep.ro/pls/dic/site.page?den=regcd1_1; accessed: 25.10.2015.
} 


\section{EXECUTIVE POWERS IN RELATIONS WITH THE PARLIAMENT. PART I}

example, by the President of Romania, the actual convene, even in an extraordinary session, is a prerogative of the Presidents of the Chambers such as is apparent from both the constitutional rule - Article 66 para (3), and the provisions of the two mentioned regulations Article 81 para (3) and Article 84 para (4). These texts of the regulations specify the fact that in the case where a request for convening in an extraordinary session does not include the mandatory indications specified above, the Chairman in question has the possibility of not taking it into consideration.

\section{Dissolution of Parliament ${ }^{10}$}

The President of Romania does not have the right to give "the start" of a new Parliament in a new legislature or to convene it in an extraordinary session, but to end a legislature before the end of the 4 year mandate, the Constitution ${ }^{11}$ recognizing his right to dissolve the Parliament. According to Article 89 from our Constitution, the President of Romania can dissolve the Parliament and not just one of its Chambers, but only if the conditions specified herein are met: the Parliament does not allow the confidence vote for forming the government within 60 days from the first request; rejection in this period of at least two requests; the consultation of the President with both Chambers and the leaders of the parliamentary groups; it should be the first and only dissolution in a year; it should not be about the last 6 month of the President's mandate and it should not be instituted one of the following states: mobilization, war, siege or emergency.

Expression of a political crisis, this "weapon" of dissolution is a direct and personal action of the President against the Parliament, not just a nomination of his competence thereof involves just putting his signature on a decree whose application lies, in fact, to the Prime Minister ${ }^{12}$. In taking this decision the President is only conditioned to consult with the presidents of the two Chambers of Parliament and with the leaders of the groups of parliament, but it is not obliged to take account of their views, the final decision belonging entirely to him. By taking this decision, the President can avoid some institutional or social blockage, particularly, in our opinion, at the time when the Government needs to cohabit with

\footnotetext{
${ }^{10}$ See O. Şaramet, "Powers of the Romanian President in relations with Parliament. Convening and dissolution of Parliament" in I. Boldea, coordinator, Debates on globalization. approaching national identity through intercultural dialogue. Studies and article. Section: Social studies, "Arhipelag Press XXI", Târgu-Mureş, 2015, pag. 721-729.

${ }^{11}$ Most constitutions recognize to the head of state - president or monarch - this right. For example, Article 88 para (1) from the Constitution of Italy provides the possibility that the Republican President to dissolve both or just one of them, after consulting the presidents of the two Houses of Parliament. In exchange, the constituent legislator from Czech Republic has recognized that the Republic's President, according to Article $62 \mathrm{c}$ ) just the right to dissolve one of the Chambers of the Parliament, respectively the Chamber of Deputies. Constitution of Italy was consulted on: https https://www.constituteproject.org/constitution/Italy_2012.pdf?lang=en, accessed: 25.10.2015. Constitution of Czech Republic was consulted on: https://www.constituteproject.org/constitution/Czech_Republic_2013.pdf?lang=en, accessed: 25.10.2015. Moreover, the Latvian Constitution, through article 48, gave the President of the Republic just the right to propose the dissolution of the Parliament, based on his proposal will be held a referendum, and if more than half of the votes cast are "for" dissolving, the Parliament will be considered as dissolved. But if, in the case where after the referendum, the Parliament is not dissolved, the responsibility belongs to the President that considers it dismissed, the Parliament choosing another President to fulfill the mandate. Constitution of Latvia was consulted on: https://www.constituteproject.org/constitution/Latvia_2014.pdf?lang=en, accessed: 25.10.2015.

12 See P. Pactet, Institutions politiques. Droit constitutionnel, Masson Publishing House, Paris, 1993, pag.390392.
} 


\section{O. Şaramet}

the Parliament, the majority of the Parliament is not in favor of the government that becomes minority, provided that the President should be "on the side" of the Government. But the dissolution is seen as a "weapon of government coalition attacks" 13 when the President is not supported in his actions by the majority of the Parliament, thus the Government becomes its exponent.

These meanings identified by the French doctrine gives the French President an active role in the relation between the executive and the legislative, stating that in this system, the President, according to Article 12 from the Constitution, can dissolve just one of the Chambers of Parliament, namely the National Assembly. However, we are not taking into consideration that such role, "fits" on the profile of the President of Romania close to a president of parliamentary republic, than the one from a semi-presidential republic, such as the French one. Nevertheless, we appreciate that exercising this attribution by the President of Romania would be more justifiable in situations where we can talk about an institutional blockage, unless it is cause and effect at the same time, while being just political games. Anyway, if he decides to dissolve the Parliament, the President must fully comply with the conditions established by constitution and classified by doctrine ${ }^{14}$ in general terms, namely: the denial of the Parliament's vote of confidence to form the Government within 60 days from the first request; the rejection of at least two requests; the prior consultation of the Presidents of the two Chambers and of the leaders of the parliamentary groups, and special conditions, as well as the rest of them that have been listed above.

\section{Addressing Parliament messages}

Another attribution of the President, in his relations to the Parliament, is the possibility or obligation of addressing messages. In this regard, Article 88 from the Constitution provides him the possibility to address messages regarding the main political issues of the nation, thus creating the possibility for the President to communicate with the Parliament, knowing that there is no subordinating relations between these two authorities, but also the fact that the President does not politically respond in front of the Parliament, like the Government. Assessment of the moment, content, form, even the way of addressing or not of the message, belongs only to the President. But the effects that such a message can produce, can not only be political or juridical, the President being unable to impose his own points of view, so as nor the Parliament can force to express its opinion regarding certain problems.

However, the President has the obligation to address a message to the Parliament when there is a case of armed aggression against the country, being forced to take urgent actions to dismiss it, actions that must be immediately communicated to the Parliament. In this case, unlike the former one, the Parliament can debate this message at the same time with the moment of its presentation ${ }^{15}$.

\section{Promulgations of laws}

\footnotetext{
${ }^{13}$ Idem, pag. 392

${ }^{14}$ A. Iorgovan, Tratat de drept administrativ, vol.I, „All Beck” Publishing House, Bucharest, 2005, pag.305.

${ }^{15}$ In this respect see the Decision of the Constitutional Court no 87/1994 on the constitutionality Article 7 from the Rules of the common sessions of the Chambers of Deputies and the Senate, published in Official Gazette of Romania, Part I, no 292, from October $14^{\text {th }} 1994$.
} 


\section{EXECUTIVE POWERS IN RELATIONS WITH THE PARLIAMENT. PART I}

The Executive does not limit itself only just to summon, dissolve the Parliament or address it a message through the President, getting involved in the lawmaking process. Thus the legislative initiative and the Government, together with the members of the Parliament, senators or a number of at least 100.000 citizens entitled to vote. In fact, most of these initiatives come from this authority, the legislation projects being submitted to the qualified Chamber to adopt it, according to Article 74, para (3) from the Constitution, as a first notified Chamber, according to Article 75 from the same legislative document. Entrusting the right of legislative initiative of the Government is, in fact, justified by the constitutional role, in the achievement of which, the Government ${ }^{16}$ it would be best qualified, knowing its realities and the existent needs in the society, knowing the legal requirements of the state, but also knowing how to promote these towards the Legislature. Both realities and needs of the society will be reflected in the explanatory memoranda that mandatory accompany the legislative projects, according to Article 29 para (1) from the Law 24/2000 on legislative techniques for drafting laws, republished with the subsequent amendments. In consideration of the constitutional provisions, Law 90/2001, with the subsequent amendments, has recognized by Article $11 \mathrm{~b}$ ), as one of the main tasks of the Government and the initiation of bills and their subjection to the Parliament, but also the one according that the Government prepares the drafts of law on the state budget and of the budget of social insurance (Article 11 e) ), as well as the enforcement of powers of the authorities and public administration laws and other legislative provisions adopted in application thereof (Article $11 \mathrm{~d}$ ) ).

Although our Constitution has not recognized the President as having the right of initiative legislature ${ }^{17}$, we should mention an exception established by Article 150 para (1) from the Constitution, republished, that states that the two authorities need to collaborate in this regard, conditioned by a proposal made by the Government, and thus the President of Romania can initiate a proposal to revise the Constitution.

If the "birth" of a law is due to mostly the implication of the Government, its publication in the Official Gazette of Romania and its entry into force is conditioned by promulgation $^{18}$ by the President. By signing the bill, the President authenticates the text of

\footnotetext{
16 The subordinating and the collaborating reports that the Government has with the ministries and other specialized bodies on the public central local administration that are subordinated to or in the subordination of or in coordination of ministries with prefectures and the bodies of public local administration, and also with the autonomous administrative authorities, allow the Government to exercise the legislative initiative including acquiring bills drafted by those authorities. To achieve a good development of the law drafting, the submission for approval, starting with February $1^{\text {st }} 2008$, entered a new regulation on procedures, at the level of the Government to elaborate, check and present the projects of documents on public politics, of projects on normative acts, and other documents, for adoption/approval, regulations approved by Government Decision 1226/2007 published in the Official Gazette of Romania, Part I, no 716 from October $23^{\text {rd }} 2007$.

${ }^{17}$ In contrast, the Latvian constituent legislator recognized, through Article 47, the right to legislative initiative of the President of the Republic.

${ }^{18}$ It is one of the recognized attributions by the majority of the modern constitutions. Such provisions are found, for examples, in Article 78 para (6) in conjunction with Article 107 from the Constitution of Estonia; section 99 point 3 ) from the Constitution of Argentina; Article 91 from the Constitution of Slovenia; article 136 b) from the Constitution of Portugal. One of the constitutions, such as the one of Czech Republic, by Article $62 \mathrm{~h}$ ) and i), recognize the right of the President to sign laws, and some of the fundamental laws of the constitutional monarchies, although entitle the head of state - monarch to sign the laws and force the ministers or secretaries of state to countersign, as applicable in the case of the Dutch Constitution which enshrined this duty to ministers or
} 


\section{O. Şaramet}

law ${ }^{19}$, finding and certifying, practically, the regularity of adoption ${ }^{20}$. The promulgation is not a discretionary measure of the President because, even if it has the possibility of resubmitting it to the Parliament for a review or to the constitutional court to monitor compliance with the Constitution, in no case has the right to refuse promulgation.

By this, the prerogative of the President is to promulgate a law distinguishing it by the prerogative taken up, at a time of monarchs, including our monarch ${ }^{21}$, to sanction laws. Basically, the head of the state manifests a reminiscent of absolute monarchy, where the law is a manifestation of royal will ${ }^{22}$, through which he would become a co-legislator ${ }^{23}$ because $^{2}$ confirming, approving the law, it participates in the legislative work, not manifesting a passive attitude of acceptance, in certain circumstances, of the adopted law by the Parliament.

Our actual constitutional provision, namely Article 77, obliges the President to promulgate the law within 20 days after receiving $i^{24}$, but it gives the possibility to seek the Parliament only once, reconsidering the law, or to ask the Constitutional Court of Romania to verify the constitutionality of the law. After receiving the adopted law, after reexamination, after receiving the decision of the Constitutional Court confirming its constitutionality, the President is obliged to promulgate the law within 10 days.

As we consider, we appreciate that the President could refer, at the same time, the same law both to the Parliament for reexamination, and the Constitutional Court on the fact that the notifications of the motives are not identical. Thus, the Parliament could be seized only for reasons of parliamentary procedure for adoption of the law, the technical- legal reasons, when the Constitutional Law can be seized for possible inconsistencies in terms of the context between the rules of law and the ones of the Constitution's, in other terms for

\footnotetext{
state secretaries in Article 47. Constitution of Netherland was consulted on: https://www.constituteproject.org/constitution/Netherlands_2008.pdf?lang=en, accessed: 25.10.2015

${ }^{19}$ In the doctrine it was appreciated the fact that the promulgating procedure is not a simple "executory force" always necessary for the law to be adopted, appearing more like a term brought in conditions of Article 146 a) from the Constitution, Constitutional Court or it can be brought in Article 77 para (2) from the same law, Parliament. It was also pointed out the fact that in the case where the President does not promulgate the law within the time and under the conditions specified in Article 77, it can appear in the Official Gazette even without being accompanied by the promulgating Act - the Presidential Decree. See in this regard T. Drăganu, Drept constituţional şi instituţii politice. Tratat elementar, vol. II, „Lumina Lex” Publishing House, Bucharest, 2000, pag.249.

${ }^{20}$ I. Muraru, S.E. Tănăsescu, Drept constituţional şi instituţii politice, C.H. Beck Publishing House, Bucharest 2006, vol.II, pag. 216.

${ }^{21}$ Article 93 para. (1) and (2) of the Romanian Constitution ofb1866 recognizes the right of our King to sanction and promulgate laws, or to refuse their sanctioning, similar provisions being found in Article 88 para. (1) and (2) of our Constitution of 1923.

22 P. Negulescu, Curs de drept constituţional român, published by Alex. Th. Doicescu, Bucharest, 1928, pag.395.

${ }^{23}$ Idem, pag.394

${ }^{24}$ A rather large term, in our opinion, compared with other provisions of other Constitutions. For example, the Constitution of Estonia, Article 107 para (2) forces the President to promulgate the law within 14 days of receipt, Article 10 para (1) from the French Constitution offers him a period of 15 days to exercise his power, by Article 91 para (1) from the Constitution of Slovenia, the President is forced to promulgate in just 8 days. Therefore, we believe that this law, this period should be reduced to at least 10 days, the interest being the completion of the legislative procedure and the entry of the law into force as quickly as possible.
} 
reasons of unconstitutionality. But, in order to promulgate the law, the President should wait for responses from both seized authorities in case he proceeded in this way ${ }^{25}$.

The possibility of our President to prevent the adoption of a law without respecting the procedures or without being subject to the rules of Constitution is however limited, and on the other hand there is a possibility and an impossibility to refuse the promulgation on the motif of inexistence of the opportunity of adopting it in the context of economy, social and political life, at that time. In contrast, the President of the USA to whom point 2 from the para 7 in the Article 1 recognizes the right to sign, no to pass the bill, but not to approve it, has the possibility to submit his objections to the Chamber where it comes from and that is forced to reconsider, in turn, Chamber which, further will send the reconsiderations to the other Chamber. Both the Senate and the House of Representatives will have to approve the draft law given the objections stated by the President of the state with two-thirds vote from each Chamber.

This complicated procedure, very often with a failure, especially if the majority of the American Congress in both Chamber or just in one is represented by the party to which the head of the state belongs, practically equals indirectly with a right to veto of the President towards the law project leading to its rejection by the President. In this situation it can be about the so called veto message ${ }^{26}$ when the action belongs to the President. But the President must express his intentions by signing or returning a bill within ten days, on the contrary the project of law will be promulgated as if he signed it. The Congress, even in this situation can stop the process of adopting a law by preventing the President to resubmit the project of law by suspending the parliamentary session, case where it can be about the veto pocket ${ }^{27}$, the action belongs to the members of the parliament through the Congress. Practically by this form of veto right, the Congress tries to cover its law project knowing that the President does not want to promulgate it and hoping that during the parliamentary recess to obtain its approval in advance.

\section{Conclusions}

When we are talking about the Romanian government, in the constitutional framework established in 1991 and revised in 2003, we are referring to the two central structures - the head of state and government, in a narrow sense of the term of executive. In this paper we intended to discuss about the most important powers exercised by the Romanian President in its relations with Parliament, and in another article will analyze the powers involving between Government and legislative power. However, we have seen from the powers mentioned above, that when the Romanian President is exercising its powers, either he collaborates with the Prime Minister, such as it is the case with the promulgation of laws, decree of promulgation must be countersigned by the latter, or consults with representatives of the

\footnotetext{
${ }^{25}$ For more details, pro and con arguments to the solution mentioned see A. Iorgovan, Tratat de drept administrativ, vol.I, „All Beck” Publishing House, Bucharest, 2005, pag.306-308.

26 J.Q. Wilson, American Government. Institutions and Policies, Harvard University and University of California, Los Angeles, 1986, pag.341

${ }^{27}$ Idem, pag. 342
} 


\section{O. Şaramet}

legislative power, such as it is the case in which the President may dissolve Parliament. Therefore, we appreciate that even as regards of these powers, the Romanian constitutional legislator has chosen a head of state who does not exercise only the function of representing the state, and the function of guarantor of national independence, unity and territorial integrity, but he shall act as a mediator between the powers in the state, by observing of the Constitution and of the proper functioning of the public authorities.

\section{Bibliography:}

- T. Drăganu, Drept constituţional şi instituţii politice. Tratat elementar, vol. II, „Lumina Lex" Publishing House, Bucharest, 2000;

- A. Iorgovan, Tratat de drept administrativ, vol.I, „All Beck” Publishing House, Bucharest, 2005;

- I. Muraru, S.E. Tănăsescu, Drept constituţional şi instituţii politice, C.H. Beck Publishing House, Bucharest, 2006, vol.II;

- P. Negulescu, Curs de drept constituţional român, published by Alex. Th. Doicescu, Bucharest, 1928;

- P. Pactet, Institutions politiques. Droit constitutionnel, Masson Publishing House, Paris, 1993;

- H. Portelli, Droit constitutionnel, Dalloz Publishing House, Paris, 1999;

- J.Q. Wilson, American Government. Institutions and Policies, Harvard University and University of California, Los Angeles, 1986;

- https://www.constituteproject.org/search?lang=en. 